DOI 10.22460/jpmi.v1i3.305-312

\title{
ANALISIS KESALAHAN SISWA KELAS IX-G DI SMP NEGERI 3 CIMAHI DALAM MENYELESAIKAN SOAL PEMECAHAN MASALAH MATEMATIK PADA MATERI LINGKARAN
}

\author{
Febriananingsih Timutius ${ }^{1}$, Nadya Rahma Apriliani ${ }^{2}$, Martin Bernard ${ }^{3}$ \\ ${ }^{1,2,3}$ IKIP Siliwangi, Jl. Terusan Jenderal Sudirman, Cimahi, Jawa Barat, Indonesia \\ ${ }^{1}$ timotiusFebriananingsih@gmail.com, ${ }^{2}$ Nadyarahmaa18@gmail.com, ${ }^{3}$ Pamartin23rnard@ gmail.com
}

Diterima: 7 Maret 2018; Disetujui: 28 Mei 2018

\begin{abstract}
The purpose of this research is to describe the student's mistake in solving the problem of mathematical problem solving. The method used in this research is descriptive qualitative. This research was conducted in class IX-G SMP Negeri 3 Cimahi with the number of students as much as 38 people. Based on the results of research conducted from the test 5 problem solving mathematical problems only $29 \%$ of students who master the problem of solving mathematical problems. The average value of students is 5.68 with highs of 13 and lows one of the maximum value of 20 . From the analysis of the responses of the students, there were some mistakes made by the students in solving the problem is: The process of settlement is not systematic, not No settlement process, directly to the answer, many do not wear the unit of length and wide, mistakenly write unit area and length, some even wearing unit volume, do not understand the problem, the conclusions are not relevant to the result of the settlement, mistaken in identifying the image, settlement which is not complete.
\end{abstract}

Keywords: Error Analysis, Problem Solving Ability

\begin{abstract}
Abstrak
Tujuan penelitian ini adalah untuk mendeskripsikan kesalahan siswa dalam menyelesaikan soal pemecahan masalah matematik. Metode yang digunakan dalam penelitian ini adalah deskriptif kualitatif. Data didapatkan dari tes tertulis soal kemampuan pemecahan masalah matematik sebanyak 5 soal. Berdasarkan hasil penelitian yang dilakukan dari tes 5 soal pemecahan masalah matematik hanya $29 \%$ siswa yang menguasai soal pemecahan masalah matematik. Rata-rata nilai siswa yaitu 5,68 dengan nilai tertingginya 13 dan nilai terendahnya 1 dari nilai maksimal 20. Dari hasil analisis yang dilakukan terhadap jawaban siswa, ada beberapa kesalahan yang dilakukan siswa dalam menyelesaikan soal tersebut yaitu: Proses penyelesaian yang tidak sistematis, tidak ada proses penyelesaian, langsung ke jawaban, banyak yang tidak memakai satuan panjang dan luas, keliru dalam menuliskan satuan luas dan panjang, bahkan ada yang memakai satuan volume, tidak memahami masalah, kesimpulan yang tidak relevan dengan hasil penyelesaiannya, keliru dalam mengidentifikasi gambar, penyelesaian yang tidak tuntas.
\end{abstract}

Kata Kunci: Analisis Kesalahan, Kemampuan Pemecahan Masalah

How to cite: Timutius, F., Apriliani, N. R., \& Bernard, M. (2018). Analisis Kesalahan Siswa Kelas IX-G di SMP Negeri 3 Cimahi dalam Menyelesaikan Soal Pemecahan Masalah Matematik pada Materi Lingkaran. JPMI - Jurnal Pembelajaran Matematika Inovatif, 1 (3), 305-312. 


\section{PENDAHULUAN}

Menurut Ruseffendi (1990) "matematika bisa diawetkan dan dikembangkan, dengan diajarkan kepada siswa di semua tingkat.dalam rangka mengembangkan dan mengawetkan matematika itu sendiri, mengawetkan maksudnya memelihara sehingga tidak punah itulah yang dimaksud dengan gunanya matematika diajarkan disekolah". Dari yang pernah dialami siswa terkadang sangat kesulitan jika menemukan permasalahan yang tujuannya tidak dapat langsung ditemukan, maksudnya ada beberapa hal yang harus mereka cari dahulu sebelum merujuk ke tujuan atau jawabannya. (Bernard, 2015) menyatakan tujuan pembelajaran matematika adalah untuk melatih kemampuan mengemukakan pendapat dengan rasa percaya diri yang sertai kejujuran untuk memecahkan masalah yang dihadapi juga melatih cara berpikir serta bernalar dalam menarik kesimpulan. Dari permasalahan yang ada ternyata kemampuan pemecahan matematik siswa masih kurang.

Polya (Hendriana, Rohaeti, \& Sumarmo, 2017) pemecahan masalah adalah suatu tujuan yang tidak begitu mudah segera dapat dicapai dari usaha mencari jalan keluar. Pentingnya pemecahan masalah yaitu membantu individu berpikir analitik, pada hakikatnya pemecahan masalah matematik adalah belajar berpikir, bernalar, dan menerapkan pengetahuan yang dimiliki, dan membantu berpikir kreatif, kritis juga mengembangkan kemampuan matematik lainnya (Hendriana et al., 2017).

Adapun indikator pemecahan masalah menurut Rosalina (Hendriana et al., 2017) yaitu: 1) mengidentifikasi unsur-unsur yang diketahui, yang ditanyakan, dan kecukupan unsur yang diperlukan, 2) merumuskan masalah matematik atau menyusun model matematik, 3) menerapkan strategi untuk menyelesaikan berbagai masalah (sejenis masalah baru) dalam atau diluar matematika, 4) menjelaskan atau menginterpretasikan hasil sesuai permasalahan awal, 5) menggunakan matematik secara bermakna.

Berdasarkan penelitian yang telah dilakukan Ruswati \& Senjayawati, 2015 di salah satu SMP di kota Cimahi Siswa masih cenderung sering melakukan kesalahan dalam setiap indikator pemecahan masalah matematik, hal ini dikarenakan kurang mampunya siswa dalam mengidentifikasi permasalahan dan kurangnya kecermatan siswa dalam melakukan perhitungan. Karena siswa merasa proses perhitungannya tidak perlu dituliskan, sehingga proses perhitungan penyelesaian yang dilakukan siswa tidak lengkap. Sedangkan berdasarkan penelitian yang dilakukan (Anggraeni \& Herdiman, 2017) Siswa sebenarnya sudah memahami soal dengan cukup baik, hal tersebut terlihat ketika siswa mampu menyebutkan apa saja yang diketahui dan ditanyakan. Akan tetapi, dalam melakukan proses perhitungan penyelesaiannya, siswa kurang sistematis. Kemudian sebagian besar siswa tidak melakukan pemeriksaan kembali terhadap penyelesaian yang dilakukan sehingga hasil penyelesaian tersebut tidak relevan (Hidayat \& Sariningsih, 2018; Wahyu, 2014).

Menyikapi permasalahan diatas, peneliti perlu melakukan studi pendahuluan untuk mengetahui kemampuan pemecahan masalah matematik siswa SMP sederajat dalam materi lingkaran.

\section{METODE}

Penelitian ini tergolong dalam penelitian deskriptif kualitatif yang bertujuan untuk mendiskripsikan kesalahan siswa dalam menyelesaikan soal lingkaran dilihat dari tingkat kemampuan pemecahan masalah matematik siswa SMP. Data penelitian ini berupa jawaban 
tertulis yang diperoleh dari tes tertulis. Sampel penelitian ini yaitu 38 siswa kelas IX-G di Smp Negeri 3 Cimahi. Adapun instrumen yang diberikan pada siswa sebanyak 5 soal.

\section{HASIL DAN PEMBAHASAN}

Berdasarkan tes yang dilaksanakan pada kelas IX-G di SMPN 3 Cimahi diperoleh gambaran kesalahan siswa dalam menyelesaikan soal-soal kemampuan pemecahan masalah matematik. Berikut adalah beberapa sempel kesalahan-kesalahan siswa dalam penyelesaian setiap soalnya

\section{Jawaban siswa pada soal no 1}

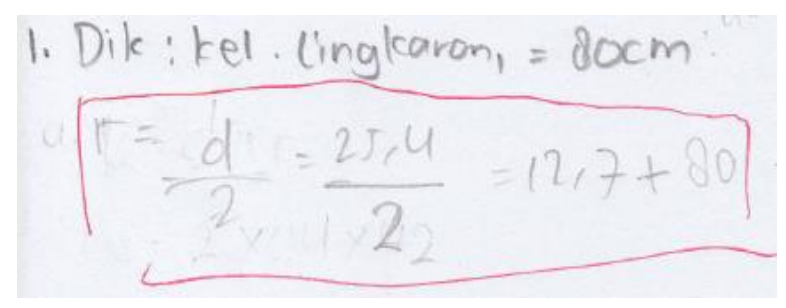

Gambar 1. Kesalahan jawaban soal 1

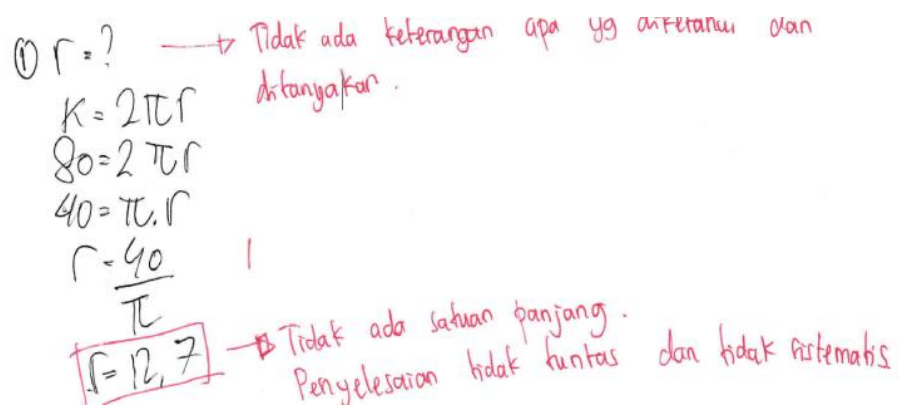

Gambar 2. Kesalahan jawaban soal 1

Siswa mencoba membuat rencana pemecahan masalah untuk soal nomor 1 , tetapi rencana tersebut tidak terproses secara sistematis dan tidak sesuai prosedur sehingga tidak ada solusi atau hasil yang benar. Saat mengidentifikasi unsur-unsur yang diperlukanpun (diketahui dan ditanyakan) tidak lengkap, ini berarti siswa tidak memahami masalah yang terdapat dalam soal nomor 1. Siswa juga tidak menuliskan satuan panjang

\section{Jawaban siswa pada soal no 2}

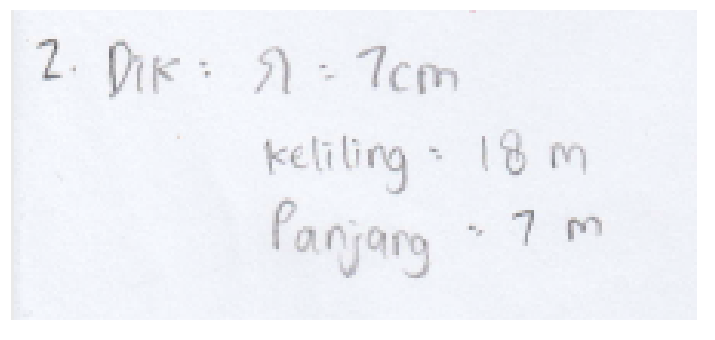

Gambar 3. Kesalahan jawaban soal 2 


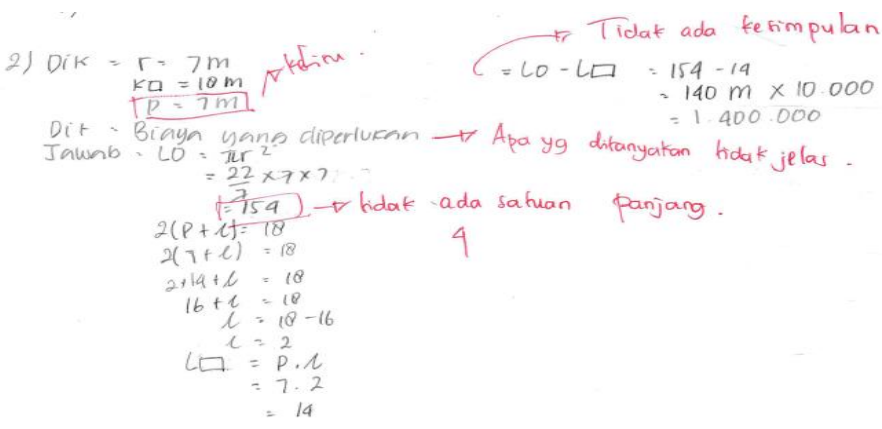

Gambar 4. Kesalahan jawaban soal 2

Terlihat jelas pada gambar bahwa siswa tidak melakukan proses penghitungan dan juga tidak membuat rencana penyelesaian untuk memecahkan masalah. Siswa hanya mengidentifikasi unsur-unsur yang diketahui. Dari hasil analisis dapat dikatakan bahwa siswa tidak memahami permasalahan yang ada pada soal nomor 2 .

\section{Jawaban siswa pada soal no 3}

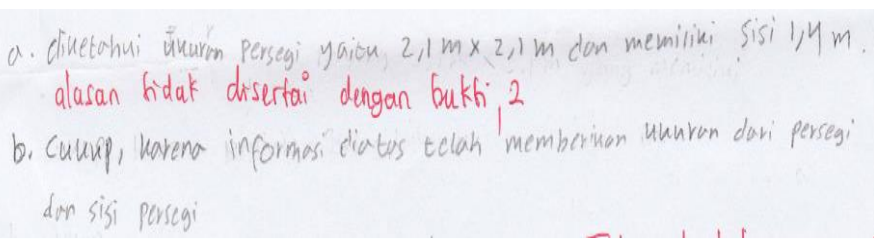

Gambar 5. Kesalahan jawaban siswa soal 3

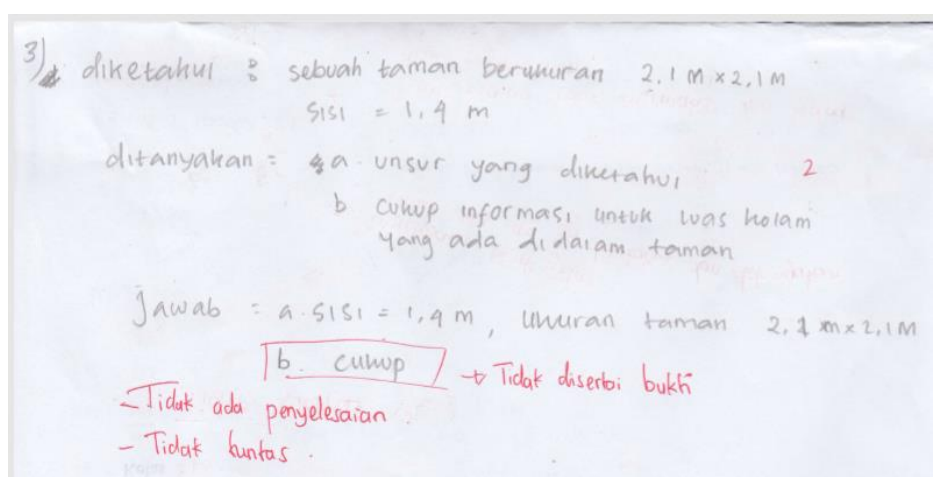

Gambar 6. Kesalahan jawaban siswa soal 3

Pada jawaban siswa nomor 3 sama halnya dengan jawaban siswa pada soal nomor 2. Siswa tidak melakukan penghitungan serta tidak ada strategi penyelesaian pemecahan masalah. Siswa hanya memberikan pendapat yang tidak disertai dengan bukti yang memperkuat pendapatnya. Dalam hal ini siswa tidak memahami soal dengan lengkap, hanya memahami sebagian masalah pada soal nomor 3 . 


\section{Jawaban siswa pada soal no 4}

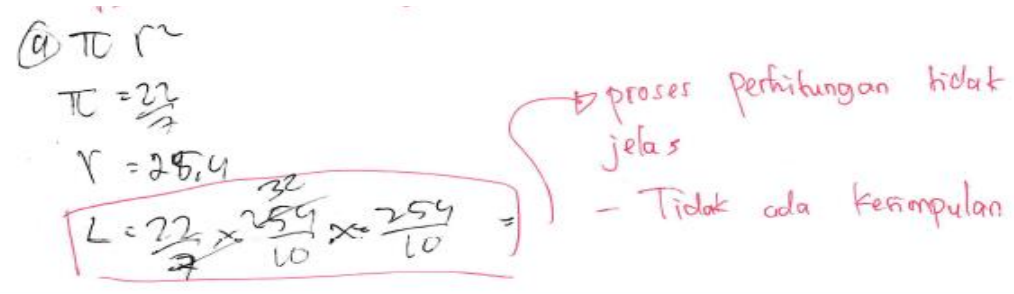

Gambar 7. Kesalahan jawaban soal 4

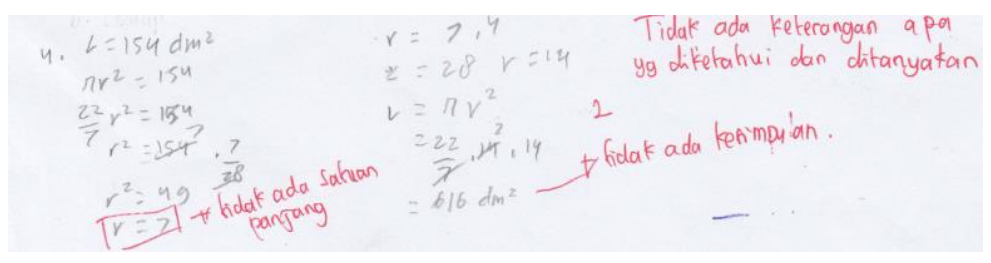

Gambar 8. Kesalahan jawaban siswa soal 4

Jawaban siswa pada soal nomor 4, siswa melakukan rencana strategi penyelesaian dan juga melakukan penghitungan. Tetapi proses penghitungan yang dilakukan tidak jelas dan juga tidak ada penarikan kesimpulan. Siswa juga tidak mengidentifikasi unsur-unsur yang diperlukan. Bisa dikatakan bahwa siswa kurang memahami soal nomor 4.

\section{Jawaban siswa pada soal no 5}

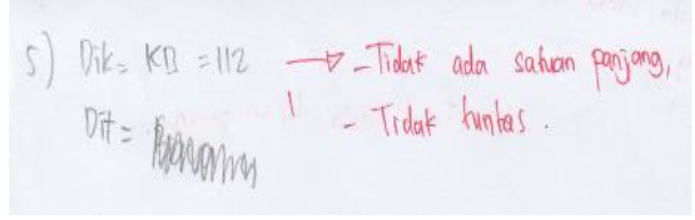

Gambar 9. Kesalahan jawaban siswa soal 5

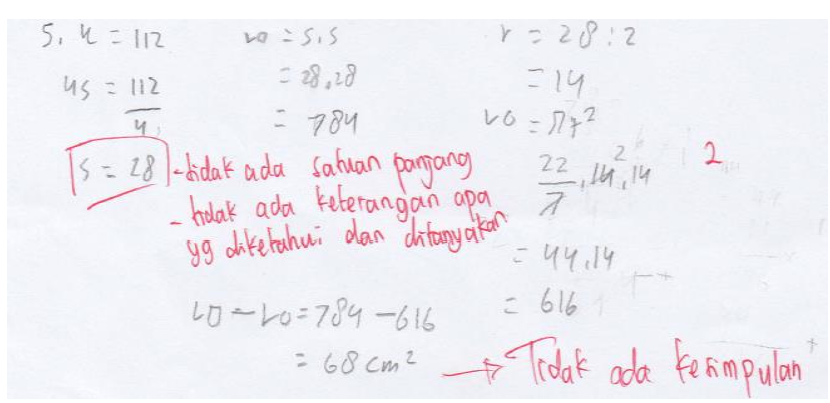

Gambar 10. Kesalahan jawaban siswa soal 5

Jawaban siswa pada soal nomor 5 sama dengan jawaban siswa nomor 2. Siswa tidak melakukan penghitungan juga tidak membuat rencana strategi penyelesaian pemecahan masalah. Siswa mengidentifikasi unsur-unsur yang diketahui tetapi siswa tidak menuliskan unsur yang ditanyakan. siswa juga tidak menuliskan satuan panjang. Sehingga siswa tidak 
tuntas dalam menyelesaikan soal karena siswa tidak memahami masalah yang terdapat pada soal nomor 5.

Dari hasil penelitian ternyata didapat rata-rata nilai siswa, standar deviasi, nilai tertinggi dan nilai terendah seperti berikut:

Tabel 1. Rata-rata, Standar Deviasi, Nilai Tertinggi dan Nilai Terendah

\begin{tabular}{cc}
\hline Rata-Rata & 5,684211 \\
\hline Standar Dev & 3,280617 \\
\hline Nilai Tertinggi & 13 \\
\hline Nilai Terendah & 1
\end{tabular}

Berdasarkan Tabel 1, rata-rata nilai siswa dari 38 siswa adalah 5,68, dan memiliki standar deviasi 3,28, dengan nilai tertingginya 13 dan nilai terendahnya 1 dari nilai maksimumnya 20 . Selain itu, penguasaan soal dari 38 siswa dalam menyelesaikan soal pemecahan masalah nomor 1 hanya 56\% untuk nomor 2 hanya $48 \%$, untuk nomor 3 hanya $10 \%$, untuk nomor 4 hanya $26 \%$ dan untuk soal nomor 5 paling rendah yaitu $7 \%$ saja.

\section{KESIMPULAN}

Berdasarkan hasil pembahasan di atas dapat disimpulkan Kesalahan-kesalahan yang dilakukan siswa yaitu: (1) Proses penyelesaian yang tidak sistematis; (2) Tidak ada proses penyelesaian, langsung ke jawaban; (3) Banyak yang tidak memakai satuan panjang dan luas; (4) Keliru dalam menuliskan satuan luas dan panjang, bahkan ada yang memakai satuan volume; (5) Tidak memahami masalah; (6) Kesimpulan yang tidak relevan dengan hasil penyelesaiannya; (7) Keliru dalam mengidentifikasi gambar; (8) Penyelesaian yang tidak tuntas.

Selain itu, dari 5 soal pemecahan masalah yang diberikan hanya $29 \%$ siswa yang menguasai soal pemecahan masalah matematik, berarti $71 \%$ siswa tidak menguasai soal kemampuan pemecahan masalah matematik. Rata-rata nilai siswa yaitu 5,68 dengan nilai tertingginya 13 dan nilai terendahnya 1 dari nilai maksimal 20.

\section{DAFTAR PUSTAKA}

Anggraeni, R., \& Herdiman, I. (2017). Analisis Kesalahan Siswa SMP dalam Menyelesaikan Soal Pemecahan Masalah Matematik pada Materi Lingkaran. In Seminar Nasional Matematika dan Pendidikan Matematika (pp. 586-592). Cimahi: STKIP Siliwangi.

Bernard, M. (2015). Meningkatkan Kemampuan Komunikasi dan Penalaran Serta Disposisi Matematik Siswa SMK dengan Pendekatan Kontekstual Melalui Game Adobe Flash CS 4.0. Jurnal Ilmiah Program Studi Matematika STKIP Siliwangi Bandung, 4(2), 197222.

Hendriana, H., Rohaeti, E, E., \& Sumarmo, U. (2017). Hard Skills dan Soft Skills Matematik Siswa. (F. Atif, N, Ed.) (1st ed.). Bandung: PT Reflika Aditama.

Hidayat, W., \& Sariningsih, R. (2018). Kemampuan Pemecahan Masalah Matematis dan Adversity Quotient Siswa SMP Melalui Pembelajaran Open Ended. JNPM (Jurnal Nasional Pendidikan Matematika), 2(1), 109-118. 
Ruseffendi, E. . (1990). Pengajaran Matematika Modern dan Masa Kini (2nd ed.). Bandung: Tarsito.

Ruswati, D., \& Senjayawati, E. (2015). Analisis Kesalahan Siswa SMP dalam Menyelesaikan Soal Kemampuan Pemecahan Masalah Matematis pada Materi Lingkaran. In Seminar Nasional Matematika dan Pendidikan Matematika (pp. 150-158). Cimahi: STKIP Siliwangi.

Wahyu, H. (2014). The Implementation of MEAs Instruction to Students' Mathematics Problem Solving and Connecting Ability. In Proceeding of International Conference on Research, Implementation and Education of Mathematics and Sciences 2014. Yogyakarta State University. 
312 Timutius, Apriliani, \& Bernard, Analisis Kesalahan Siswa Kelas IX-G di SMP ... 